\title{
Budget boost for science
}

\section{Washington}

SCIENCE fares well in this year's US budget proposals - with a 13 per cent increase compared to a 2.6 per cent rise in the budget overall. Here are the details.

\section{National Institutes of Health}

President Bush has asked for a record total of nearly $\$ 8,800$ million for the NIH, including nearly $\$ 830$ million for AIDS research alone. At a stated increase of 5.8 per cent, once inflation is taken into account, the AIDS research budget is holding steady. The current NIH budget is $\$ 8,200$ million.

Disputes over the NIH budget have recently centred on whether the institutes can fund 6,000 new grants a year, a figure that advocates of investigator-initiated awards have set as something of a holy grail. Under the Bush budget, even with an increase of 9 per cent for individual grants, it is not likely that NIH can fund 6,000 new and competing grants at the full amount a researcher requests.

\section{Department of Energy}

The $\$ 6,400$ million $R \& D$ budget is up only 4 per cent from 1991, not likely to be enough to cover inflation, but it somehow finds funds to keep the Superconducting Super Collider on track with $\$ 534$ million. That is a 120 per cent growth from fiscal year 1991 as the projected $\$ 8,200$ million project begins to build up. Support for other high-energy and nuclear physics research is projected at $\$ 1,010$ million, a 12 per cent increase.

DOE will get the lion's share of the $\$ 903$ million planned for Bush's National Energy Strategy: \$653 million, up 26 per cent from fiscal year 1991. Much of the total will go towards reducing energy consumption and finding alternative fuels, but $\$ 314$ million is earmarked for advanced energy technologies, including solar power, superconductivity and R\&D on advanced nuclear reactor designs. The fusion programme would be boosted by 23 per cent to $\$ 337$ million, part of it allotted for R\&D and design work on a burning plasma experiment at Princeton's Plasma Fusion Laboratory and part to continue participation in the collaborative International Thermonuclear Engineering Reactor.

\section{NASA}

The $\$ 15,700$ million budget, a 13 per cent increase over 1991, includes money for boosting basic space science research, expanding space exploration and improving the reliability of getting into space. To provide for improvements to the Space Shuttle as new technology becomes available, Bush proposes a new $\$ 122$ million Assured Shuttle Availability programme; in tandem, the budget asks for $\$ 350$ million, to be split evenly between NASA and the Department of Defense, for development of a new launch system.

To pay for a burgeoning crop of space science studies, including the Mars Observer, the Gamma Ray Observer and the Advanced X-Ray Astrophysics Facility, the budget calls for $\$ 2,100$ million, a 21 per cent increase over this year's figures. The Space Station Freedom fares relatively poorly in the budget - only an 8 per cent increase to $\$ 2,200$ million - but exploration of the Solar System would draw $\$ 256$ million, a jump of 65 per cent, to be shared with the energy and defence departments.

\section{National Science Foundation}

President Bush once again reaffirmed his commitment to doubling NSF's budget by 1994 with a 17.5 per cent increase over fiscal year 1991. If the increase is approved by Congress, NSF would be "back on the doubling track" that began in 1987 under the Reagan administration, says NSF acting director, Frederick M. Bernthal. afforded to education by the Bush administration, and as part of a new FCCSET initiative, funding for education fares well. Support for pre-college science and mathematics education is up 19 per cent to $\$ 253$ million, with a 30 per cent increase (\$133 million) at the undergraduate level.

NSF has requested $\$ 23.5$ million to begin construction on two identical, but widely separated, detectors that form part of the laser interferometry gravitational wave observatory, and $\$ 16$ million towards the first of two 8-metre optical/ infrared telescopes, a collaborative research effort to include the United Kingdom and, possibly, Canada.

A request of $\$ 50$ million has been made to fund a new instrument initiative that is aimed primarily at individual researchers. Grants of between $\$ 100,000$ and $\$ 2$ million will be awarded as part of a competitive merit-based programme.

One stipulation is that the federal allocation must be matched equally with funds from non-federal sources.

\section{Science education}

One of the toughest issues facing the United States is the dismal state of education in science and mathematics from grammar school right on through college.

\begin{tabular}{|c|c|c|c|c|}
\hline \multicolumn{5}{|c|}{$\begin{array}{l}\text { MATHEMATICS, SCIENCE, AND ENGINEERING EDUCATION } \\
\text { (\$MILLION) }\end{array}$} \\
\hline & $\begin{array}{l}\text { Enacted } \\
1991\end{array}$ & $\begin{array}{l}\text { Proposed } \\
1992\end{array}$ & $\begin{array}{l}\text { Dollar } \\
\text { change }\end{array}$ & $\begin{array}{l}\text { Per cent } \\
\text { change }\end{array}$ \\
\hline \multicolumn{5}{|c|}{ By educational level: } \\
\hline Pre-college & 515 & 661 & +146 & +28 \\
\hline Undergraduate & 417 & 477 & +60 & +14 \\
\hline Graduate & 784 & 803 & +19 & +2 \\
\hline Total & 1.716 & 1,941 & +225 & +13 \\
\hline \multicolumn{5}{|l|}{ By agency: } \\
\hline Defence & 416 & 416 & - & $\overline{-1}$ \\
\hline Education & 235 & 330 & +95 & +40 \\
\hline Health and & & & & \\
\hline Human Services & 486 & 513 & +27 & +6 \\
\hline NSF & 372 & 456 & +84 & +23 \\
\hline Other & 207 & 226 & +19 & +9 \\
\hline Total & 1,716 & 1.941 & +225 & +13 \\
\hline
\end{tabular}

NSF funding for a high-performance computing and communications initiative, which is coordinated through the Federal Coordinating Council on Science, Engineering and Technology (FCCSET), will total $\$ 213$ million, a 26 per cent increase. With contributions from the Defense Advanced Research Projects Agency, DOE, NASA, and other agencies, the computing initiative is budgeted at a total of $\$ 638$ million, up 149 per cent from fiscal year 1991 .

A second FCCSET initiative, the US Global Change Research Program, is projected for $\$ 1,186$ million, a 232 per cent leap, divided among NSF, NASA, DOE, the National Oceanic and Atmospheric Administration and several others.

NSF's share of the programme is $\$ 118.5$ million, a 36 per cent increase.

In keeping with the high priority
Bromley has called US science and mathematics education a "scandal", a point that the budget document picks up in less vivid terms. The typical US school year is short at 180 days, compared with Japan, where students are in school 240 days a year, or Europe, where the school year is 200 days.

"Moreover", the budget statement notes, "American students do not work very hard". Although individual states bear the primary responsibility for education in the United States, the Bush budget proposes spending through a range of federal agencies on teacher training, curriculum reform and technical assistance in science and mathematics teaching, for a total expenditure of $\$ 1,941$ million, up 13 per cent from this year.

Barbara J. Culliton, Robert Pool \& Diane Gershon 